\title{
Polsko-czeska pamięć historyczna a przełomowe momenty wspólnych dziejów
}

W prezentowanym artykule zajmę się tymi wydarzeniami we wspólnej historii, które odgrywały lub odgrywają nadal ważną rolę we wzajemnych relacjach polsko-czeskich. Następnie spróbuję określić, jakie czynniki wpływają na kształt polsko-czeskiej pamięci w odniesieniu do najważniejszych momentów wspólnej historii. Postaram się sprawdzić, w jaki sposób dane wydarzenie było lub jest obecne w polskiej i czeskiej pamięci zbiorowej. Następnie zatrzymam się nad kwestią wykorzystania wybranych treści historycznych w polityce zagranicznej Polski. Na koniec zastanowię się nad tym, czy próby budowania polityki historycznej podejmowane są jedynie przez elity sprawujące władzę.

Trudno zaprzeczyć, że dobre stosunki polsko-czeskie są jednym $\mathrm{z}$ ważnych celów polskiej polityki zagranicznej. Niemniej jednak, mają one charakter poniekąd unikalny i różnią się w sposób zdecydowany nie tylko od kontaktów Polski ze znaczącymi mocarstwami, takimi jak Rosja czy Niemcy, ale także krajami takimi jak Litwa, Ukraina czy Białoruś. Czechy nie są bowiem ani globalnym graczem w światowej polityce, ani nie stanowiły nigdy części Rzeczypospolitej Obojga Narodów. Leżące przez większość swojej historii w orbicie wpływów niemieckich, podążały zazwyczaj własną drogą. To zaskakujące, że kraje, które dzielą ze sobą, od czasu rozpadu Czechosłowacji, granicę o długości blisko $800 \mathrm{~km}$ wchodziły ze sobą w interakcję, co do zasady, jedynie przy okazji ważniejszych dla obu narodów wydarzeń. Jak stwierdził kiedyś Tomasz

Doktor, Politechnika Łódzka, Wydział Zarządzania i Inżynierii Produkcji, Zakład Nauk Humanistycznych. 
Jastrun, komentując wyniki ankiety dotyczące wizerunku Czechów w oczach warszawskich licealistów w 1988 roku, można odnieść wrażenie, że Polaków i Czechów oddziała „lodowaty ocean” ${ }^{1}$. Elżbieta Szczepańska wskazuje z kolei na fakt, że istnieje wiele powodów takiego stanu rzeczy, ale większość z nich, o ile nie wszystkie, ma korzenie we wspólnej historii. Pośród nich publicystka wymienia zwłaszcza panslawizm dominujący w XIX-wiecznym czeskim odrodzeniu oraz konflikty w XX wieku². Sprawa wydaje się jednak bardziej złożona, bowiem na postrzeganie wspólnej, polsko-czeskiej przeszłości ma wpływ kilka czynników pozahistorycznych. Pierwszym z nich jest sposób interpretacji własnej historii przez daną wspólnotę narodową. Nie ulega bowiem wątpliwości, że narody patrzą na swoje dzieje jako na rezultat procesu posiadającego pewne „motywy przewodnie”. Co więcej, poszczególne wydarzenia są przeżywane odmiennie przez tych, których one bezpośrednio dotyczą, inaczej patrzy na nie naród, a jeszcze inaczej interpretuje je elita sprawująca władzę. Nie należy wreszcie zapominać o wpływie stereotypów i mitów narodowych na relacje międzynarodowe, ponieważ często stanowią one jeden $\mathrm{z}$ aspektów zbiorowej wiedzy na dany temat ${ }^{3}$. Jak słusznie zauważyła Justyna Dojnik, w tym ostatnim przypadku konkretne wydarzenia historyczne nie są jednak źródłem poszczególnych sądów, ale siłą, która je wyzwala ${ }^{4}$.

\section{Przełomowe wydarzenia w polsko-czeskiej pamięci historycznej}

Nie ulega wątpliwości, że bitwa pod Białą Górą (8.11.1620) stanowi jedno $\mathrm{z}$ najbardziej traumatycznych doświadczeń narodu czeskiego. Warto tu przywołać opinię Josefa Pekařa, który nazywa wspomnianą klęskę „nieszczęściem

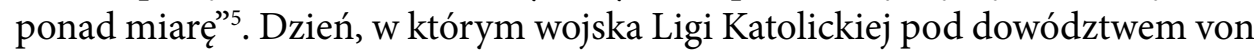
Tilly’ego pokonały wojsko Krystiana Anhalckiego rozpoczął prawie trzystuletni czas niewoli narodu czeskiego oraz narzuconego katolicyzmu, przy bezlitosnym rugowaniu protestantyzmu i wymazywaniu wszelkich tradycji husyckich.

1 T. Jastrun, Hipopotam, czyli jak polska młodzież licealna widzi Czechosłowacje, „, Res Publica” 1988, nr 12, s. 56.

2 E. Szczepańska, Wizerunek Czecha w „Zrób sobie raj” czy może kreowanie nowych stereotypów, „Bohemistyka” 2013, nr 4, s. 288-289.

3 A. Sepkowski, Człowiek w przestrzeni mitycznej, [w:] Mity historyczno-polityczne, wyobrażenia zbiorowe, polityka historyczna. Studia i materiały, t. 1, E. Ponczek, A. Sepkowski (red.), Toruń 2010, s. 23.

4 J. Dojnik, Mity narodowe a myślenie polityczne, [w:] E. Ponczek, A. Sepkowski (red.), op. cit., s. 54-55.

5 J. Pekař, O smyslu českých dějin, Praha 1999, s. 274. 
Jak zauważa Howard Louthan, w kulturze popularnej wspomniane wydarzenie zaczyna okres upadku (temno $)^{6}$. Pomijając egzekucje i konfiskaty mienia tych spośród przywódców, którzy nie zdążyli zbiec za granicę, zwycięski Ferdynand II Habsburg rozpoczął w pokonanym kraju kontrreformację. W wyniku represji, głodu i zniszczeń wojennych, do końca wojny trzydziestoletniej ziemię utraciły tysiące czeskich rodzin protestanckich, a liczba ludności spadła przynajmniej o jedną trzecią ${ }^{7}$.

Na rolę bitwy pod Białą Górą w świadomości czeskiej zwróciła uwagę m.in. Aleksandra Pająk. Wspomniana badaczka wskazuje na ciekawą obserwację czeskiego eseisty Miloša Martena dotyczącą losów protestantów czeskich po bitwie pod Białą Górą. Według niej, egzekucję przywódców powstania z 1621 roku porównać można do nocy świętego Bartłomieja we Francji ${ }^{8}$. Z jednej strony liczba ofiar jest w pierwszym przypadku znacząco mniejsza. Trudno jednak zaprzeczyć, iż polityczne konsekwencje roku 1620 były dla Czechów przynajmniej równie brzemienne co noc świętego Bartłomieja. W okresie trwania Republiki Czechosłowackiej pamięć o Białej Górze nadal funkcjonowała jako symbol klęski i poniżenia narodu czeskiego. Pomimo upływu trzech stuleci to właśnie konieczność „odczarowania” tej historycznej przegranej stała się fundamentem jednego z najważniejszych świąt Republiki Czechosłowackiej. Rolę bitwy pod Białą Górą słusznie dostrzegają Dagmar Hájková oraz Nancy M. Wingfield ${ }^{9}$. Uczone podkreślają, że upamiętnienie zwycięskiej dla Czechów bitwy pod Zborowem w 1917 roku było drugim najważniejszym świętem państwowym po I wojnie światowej ${ }^{10}$. Chociaż wspomniana batalia stanowiła $\mathrm{w}$ istocie element rosyjskiej ofensywy przeciwko Austro-Węgrom, to $\mathrm{w}$ ofensywie pod Zborowem brała udział brygada złożona $\mathrm{z}$ ochotników i dezerterów czeskich, których sformowano w jednolitą etnicznie jednostkę ${ }^{11}$. W odczuciu Czechów wspomniana bitwa stanowiła rewanż za klęskę pod Białą Górą. Może budzić zdziwienie fakt, iż w celu zamazania poczucia klęski, Czesi

6 H. Louthan, The Charles Bridge and Czech Identity, Washington 2006, s. 1.

7 E. Bakke, Doomed to Failure? The Czechoslovak Nation Project and the Slovak Autonomist Reaction 1918-1938, Oslo 1999, s. 102. Co więcej, pojawienie się w kraju jezuitów pociągnąć miało za sobą upadek czeskiego języka, bowiem wiele zabytków piśmiennictwa uznanych zostało za dzieła heretyków i zniszczone. Jakby tego było mało, większość napływowych rodzin stanowili Niemcy, którzy zastąpili czeskich protestantów.

8 A. Pająk, Głos Miloša Martena w sporze o sens czeskich dziejów, „Bohemistyka” 2009, nr 2, s. 84.

9 D. Hájková, N.M. Wingfield, Czech(-oslovak) National Commemorations During the Interwar Period: Tomás G. Masaryk and the Battle of White Mountain Avenged, „Acta Histriae" 2010, no. 18, s. 434-435.

10 Ibidem, s. 434.

11 Ibidem, s. 435-436. 
zdecydowali się na upamiętnienie bitwy, która była jedynie elementem ofensywy prowadzonej przez inne mocarstwo. Trzeba jednak przyznać, iż bitwa pod Zborowem spełnia wszystkie kryteria, by znacząco zaistnieć w czeskiej pamięci zbiorowej. Batalia nie tylko przypadła na czas trzechsetnej rocznicy bitwy pod Białą Górą, ale również prowadzona była z dalekimi „spadkobiercami” tradycji Ligi Katolickiej, tj. Austro-Węgrami ${ }^{12}$. Ewolucja czeskiego podejścia do klęski pod Białą Górą jest bardzo ciekawa, ponieważ stanowi ilustrację ewolucji mitu. Oto bowiem wydarzenie bezsprzecznie tragiczne, służące do 1917 roku jako memento przed ekspansjonizmem niemieckim, stało się elementem mitu zwycięskiego odwetu na germańskim przeciwniku.

W trakcie powstania czeskiego na porządku dziennym stanęła sprawa orientacji politycznej reprezentowanej przez Rzeczpospolitą Obojga Narodów, a konkretnie jej króla Zygmunta III Wazę oraz polsko-litewski sejm i senat. Zgodnie z traktatem zawartym pomiędzy królem polskim a Habsburgami, strony obiecywały sobie wzajemną pomoc w przypadku buntu poddanych oraz pozwalały na zaciąg wojsk najemnych na swoim terytorium ${ }^{13}$. Warto przypomnieć, że po wybuchu buntu stanów czeskich w 1619 roku Zygmunt III próbował prowadzić mediację pomiędzy zwaśnionymi stronami, a na zaciąg wojsk najemnych pozwolił Ferdynandowi dopiero, gdy ten został zdetronizowany i wybrano na jego miejsce palatyna Renu Fryderyka $\mathrm{V}^{14}$. Warto podkreślić, iż była to jedyna pomoc, jakiej Rzeczpospolita Obojga Narodów udzieliła Habsburgom, aczkolwiek zawarty sojusz uzasadniałby znaczne zaangażowanie armii Korony na rzecz rozstrzygnięcia sporu między Czechami a Habsburgami.

Zastanawiając się nad obecnością Polaków w czeskiej pamięci zbiorowej, w odniesieniu do bitwy pod Białą Górą należy przyznać, że wsparcie udzielone przez lisowczyków Lidze Katolickiej nie przekłada się na złe skojarzenia pomiędzy naszymi narodami. Dzieje się tak z kilku powodów. Z perspektywy zmagań o własną narodowość trudno postrzegać udział Polaków we wspomnianej bitwie jako dużą krzywdę, chociażby dlatego, że czeska pamięć posiada mocniejszą "pożywkę" w tym względzie zarówno w wiekach wcześniejszych, jak i późniejszych. Co więcej, w pamięci zbiorowej Czechów wojna ta zapisała się jako konflikt pomiędzy ich narodem a Habsburgami, reprezentującymi żywioł niemiecki. Drugą płaszczyzną niezgody był spór pomiędzy protestantami (reprezentowanymi przez opcję czeską) a katolikami (na których czele stali Habsburgowie). Oczywiście, Czesi mają świadomość, że w szeregach Ligi Katolickiej walczyli nie tylko

\footnotetext{
12 M. Zückert, Zwischen Nationsidee und staatlicher Realität. Die tschechoslowakische Armee und ihre Nationalitätenpolitik 1918-1938, München 2006, s. 56-57.

13 M. Markiewicz, Historia Polski 1492-1795, Kraków 2004, s. 461.

14 Ibidem, s. 462.
} 
Niemcy, ale także Hiszpanie oraz Polacy, reprezentowani przez najemnych lisowczyków. Najważniejszy powód, dla którego „Biała Góra” nie wpływa na stosunki obu narodów leży jednak gdzie indziej. Jak słusznie podkreślił Sławomir Nowinowski, punktem odniesienia dla czeskiej narodowej tożsamości, a tym samym pamięci zbiorowej, jest ich historia w XX wieku' ${ }^{15}$.

Wydarzeniem, które we wspomnianym okresie oraz później oddziaływało na wzajemne polsko-czeskie relacje jest sprawa zajęcia Zaolzia przez Polskę w 1938 roku. Współcześni badacze polscy wskazują przede wszystkim, że w całej omawianej sprawie zaistniała pewna asymetria, którą dostrzegają zarówno polskie, jak i czeskie zbiorowości lokalne. Jak słusznie podkreślają Halina Rusek oraz Andrzej Kasperek, o ile zajęcie Zaolzia przez wojsko polskie w 1938 roku urosło do rangi głośnego i wstydliwego wydarzenia w polskiej historii, o tyle wkroczenie wojsk czechosłowackich na teren polskiej części Śląska Cieszyńskiego w 1919 roku nie doczekało się potępienia w historiografii naszych południowych sąsiadów ${ }^{16}$. Warto przy tym podkreślić, że w przypadku aneksji Zaolzia w 1938 roku obyło się bez ofiar wśród żołnierzy, a z wcześniejszym czechosłowackim zaborem tego terenu wiąże się sprawa tzw. masakry w Stonawie, gdzie podczas agresji naszego południowego sąsiada 14 żołnierzy wadowickiego pułku piechoty zostało zamordowanych po wzięciu do niewoli, a trzech zginęło w wal$\mathrm{ce}^{17}$. Niemniej ważnym wydarzeniem był krótki okres po przejściu frontu przez Zaolzie w maju 1945 roku, kiedy to Polakom wydawało się, że sporny teren wejdzie w skład powojennej Polski. Zgodnie z relacją jednego z autochtonów:

we wszystkich miastach i wsiach Zaolzia z entuzjazmem i spontanicznie wznawiano przedwojenną, polską administrację i samorząd terytorialny [...]. Z radością jednak i Mazurkiem Dąbrowskiego na ustach oraz pieśnią Boże coś Polskę w kościołach dziękowano 9 maja Bogu i zwycięzcom za pokonanie faszystowskiej bestii i za koniec straszliwej wojny. Radość tę niebawem zamienił w trwogę marszałek Związku Radzieckiego N.A. Bułganin oficjalnym oświadczeniem 18.V.1945, że na Zaolziu będzie się zaprowadzać czechosłowacką administrację ${ }^{18}$.

15 S. Nowinowski, Glosa do sporu o sens czeskich dziejów, [w:] Pamięć i polityka historyczna. Doświadczenia Polski i jej sq̨siadów, S.M. Nowinowski, J. Pomorski, R. Stobiecki (red.), Łódź 2008, s. 49.

16 H. Rusek, A. Kasperek, Sympatie i antypatie polsko-czeskie w świetle badań nad antagonizmem i pojednaniem polsko-czeskim na Ślasku Cieszyńskim, [w:] Pogranicze - Sąsiedztwo - Stereotypy. Przypadek polsko-czeskich relacji wraz z francusko-niemieckim case study, A. Kasperek (red.), Katowice-Cieszyn 2012, s. 103. Uczeni przywołują wypowiedź dyrektora z Książnicy Cieszyńskiej, który wprost podkreśla, iż istnieje olbrzymia asymetria w przeżywaniu epizodu Zaolzia po stronie czeskiej i polskiej.

17 G. Gąsior, Stawianie granicy, „Karta. Kwartalnik Historyczny” 2008, nr 55, s. 22.

18 A. Sęk, Zawieruchy wojennej ciag dalszy, „Zaolzie. Polski Biuletyn Informacyjny” 2004, nr 11, s. 3 . 
Sprawa ta została inaczej zapamiętana w perspektywie lokalnej, a inaczej w perspektywie ogólnonarodowej, o czym mowa będzie w dalszej części artykułu. Warto jednak zaznaczyć, iż próżno szukać podobnych przykładów samokrytyki w historii czeskiej, jak sprawa Zaolzia, w doświadczeniu polskiej pamięci zbiorowej, jeśli chodzi o 1938 rok.

Jednym z najważniejszych wydarzeń historycznych, które należy uznać za istotne z perspektywy polsko-czeskiej pamięci historycznej jest interwencja państw Układu Warszawskiego w Czechosłowacji w 1968 roku, w odpowiedzi na wydarzenia "praskiej wiosny”. Jak wiadomo, jednym z pięciu państw Układu, którego wojska wkroczyły z „bratnią pomocą" była Polska Rzeczpospolita Ludowa ${ }^{19}$. Jan Kalous, będący autorem jednego z najważniejszych opracowań dotyczących wspomnianej kwestii, słusznie wskazuje na fakt, iż we wspomnianym wydarzeniu należy wziąć pod uwagę to, że formacje Ludowego Wojska Polskiego działały na bardzo ograniczonym terenie Czechosłowacji, w dość krótkim czasie (sierpień-październik 1968 roku) ${ }^{20}$.

Zarówno przywództwo wojsk PRL, jak i władze Czechosłowacji wydały przy tej okazji stosowne oświadczenia. Oba pisma zawierają ważne z punktu widzenia tego artykułu informacje. Najważniejsze aspekty polskiego dokumentu to przede wszystkim deklarowana chęć pomocy w obliczu zagrożenia „reakcją" oraz nawiązanie do pozytywnych aspektów dotychczasowej wspólnej historii, tj. wspólnego zwycięstwa pod Grunwaldem, walki z hitleryzmem i wysiłku odbudowy powojennej ${ }^{21}$. Oczywiste jest to, że z zupełnie innej perspektywy patrzyły na tę kwestię władze czechosłowackie. Widać to dobrze na przykładzie listu Komitetu Wojewódzkiego KPCz do Komitetu Wojewódzkiego PZPR we Wrocławiu, na który słusznie wskazał cytowany już Jan Kalous ${ }^{22}$. W owym piśmie mowa jest o zniszczonej jedności, którą Czesi i Polacy budowali przez wiele lat. Trzeba jednak zauważyć, że mówiąc o wspólnej historii, czechosłowaccy działacze komunistyczni nawiązali do walki przeciw hitleryzmowi, burżuazji oraz budowania socjalizmu. Wspomniane pismo jest ważne nie z powodu swojej zawartości, ale z powodu tego, czego w nim nie ma. Wszystkie te „wspólne” wysiłki jednoczące Czechów i Polaków miały bowiem miejsce

19 Terminem tym posłużyłem się nieprzypadkowo, ponieważ w tym przypadku odpowiedzialność za powstałe/spotęgowane przekonania i stereotypy nie leży po stronie narodu polskiego. Jak powszechnie wiadomo, decyzja o wkroczeniu wojsk Układu Warszawskiego, w tym wojsk polskich, na teren Czechosłowacji zapadła w Moskwie.

20 J. Kalous, Reakcje społeczeństwa czechosłowackiego na udział Polski w interwencji 1968 roku, [w:] Wokół Praskiej Wiosny, Ł. Kamiński (red.), Warszawa 2004, s. 117.

21 V. Matouš, J. Juza, Svědectví o roku 1968 v okrese Rychnov n.Kn., Rychnov nad Kněžnou 1992, s. 87-88.

22 J. Kalous, op. cit., s. 123. 
dopiero w XX wieku. Co więcej, nie zostały one podyktowane suwerenną decyzją obu narodów, a jedynie wymogiem chwili lub ograniczoną suwerennością. We wspomnianych pismach nie ma mowy o innych przykładach wspólnego dziedzictwa i przyjaźni. Reasumując, powyższe dokumenty świadczyły o relatywnej kruchości „przyjaźni” polsko-czeskiej.

Rozważając zagadnienie stosunku zwykłych obywateli do problemu interwencji, trzeba pamiętać, że nie przeprowadzono w owym czasie sondażu ankietowego. Dysponujemy więc jedynie jednostkowymi przykładami reakcji na interwencję państw Układu Warszawskiego. Zdarzały się wówczas przykłady „wyzywania” polskich żołnierzy różnymi inwektywami ${ }^{23}$. Były także incydenty utrudniania działania wojskom okupacyjnym PRL, np. poprzez dokonywanie zamiany drogowskazów i kierowanie Polaków w złym kierunku ${ }^{24}$. Zdarzały się wreszcie przypadki agresji fizycznej wobec żołnierzy polskich ${ }^{25}$. Podstawową i najbardziej powszechną reakcją był jednak bierny opór i ignorowanie polskich wojsk okupacyjnych, objawiające się niekiedy odmową obsługi w barach gastronomicznych ${ }^{26}$. Szczególny charakter miały antypolskie reakcje na Śląsku Cieszyńskim. Warto jednak zauważyć, że na obszarze, na którym przyszło działać okupacyjnym wojskom PRL wraz z upływem czasu dochodziło pomiędzy Czechami a Polakami do przypadków zrozumienia, a nawet przyjaznych kontaktów. Na przykład na terenie Kostelca, po okresie nieufności, lokalny dowódca czechosłowacki pozwolił się myć polskim żołnierzom w lokalnych koszarach $^{27}$. Zbigniew Ślusarczyk słusznie wskazuje na dyscyplinę Polaków jako powód, dla którego byli oni dla lokalnej ludności stosunkowo znośni i w obiegowej opinii mniej niebezpieczni niż żołnierze radzieccy ${ }^{28}$. Nie ulega jednak wątpliwości, że w większości przypadków dominującym uczuciem była jednak rezerwa Czechów i wstyd Polaków ${ }^{29}$. Epizod interwencji wojsk PRL w Czechosłowacji jest ciekawy dlatego, że nastąpił nie z wyboru Polaków, a jednak przyczynił się do pogłębienia negatywnych stereotypów.

Podsumowując ten fragment artykułu, można wyciągnąć kilka wniosków. Po pierwsze, pomimo udziału polskich najemników w bitwie pod Białą Górą,

${ }^{23}$ Najpopularniejsze okrzyki i napisy, z jakimi zetknęli się polscy żołnierze to „faszyści”, „Polacy zdrajcy” czy „Warszawa 400 km”. Z. Ślusarczyk, Opowieści spod spadochronowej czaszy, Kraków 1992, s. 132-134.

24 J. Kalous, op. cit., s. 121.

25 Ibidem, s. 122.

26 Ibidem, s. 124.

27 Z. Ślusarczyk, op. cit., s. 133-134.

28 Ibidem, s. 139.

29 L. Kowalski, Kryptonim „Dunaj”: udział wojsk polskich w interwencji zbrojnej w Czechosłowacji $w 1968$ roku, Warszawa 1992, s. 195. 
w zbiorowej pamięci czeskiej trudno doszukać się pretensji wobec Polaków. Jest tak przede wszystkim dlatego, że obecność lisowczyków nie wpisywała się dostatecznie mocno w mit konfliktu pomiędzy żywiołem czeskim a niemieckim. Po drugie, w przypadku czeskiej agresji na Śląsk Cieszyński i polskiej aneksji Zaolzia istnieje asymetria w poczuciu winy. Relatywnie duże poczucie winy po stronie polskiej kontrastuje $\mathrm{z}$ brakiem żalu lub choćby refleksji po stronie czeskiej za masakrę pod Stonawą. Być może ciekawszym źródłem do badań są jednak korzenie polskiego wstydu, a nie czeskiej obojętności. Aneksja Zaolzia stanowi bowiem podważenie wyobrażenia Polaków o sobie samych jako narodzie, który nie jest agresorem. Tę samą genezę wydaje się mieć polski wstyd za udział w tłumieniu Praskiej Wiosny. Co ciekawe, można by się spodziewać, że wspomniane wydarzenie mocniej przyczyni się do pogłębienia wzajemnej niechęci. Przytoczona powyżej korespondencja pomiędzy stroną czechosłowacką a polską wskazuje jednak, że gdy przyszło do wymienienia przykładów solidarnej współpracy obu narodów z przeszłości, lista była niezwykle krótka. Dowodzi to raczej braku poczucia wspólnoty. Polacy nie odgrywają również w czeskiej mitologii narodowej dużej roli i odwrotnie.

\section{Determinanty pamięci zbiorowej}

Zasadniczą kwestią utrudniającą rzetelną analizę pamięci historycznej z perspektywy czeskiej jest fakt, iż do tej pory toczy się tam spór na temat motywu przewodniego czeskich dziejów. Według niektórych przedstawicieli czeskich elit, zasadniczym sensem była walka o tożsamość narodową, zaś według innych dużą rolę odegrał mesjanizm czeski, objawiający się w propagowaniu w toku historii wartości demokratycznych, i wyjątkowość religijna ${ }^{30}$. W okresie czeskiego odrodzenia narodowego spójną koncepcję sensu czeskich dziejów sformułował František Palackýs $y^{31}$. Wspomniany uczony dowodził, że przewodnim motywem historii narodu czeskiego jest wyzwolenie spod niemieckich wpływów kulturowych ${ }^{32}$.

30 A. Pająk zauważa, że istota sporu o sens czeskich dziejów przybiera formę dylematu, sprowadzającego się do tego, czy należy go szukać w procesie walki o tożsamość narodową, czy też posłannictwo religijne: A. Pająk, op. cit., s. 81.

31 Wspomniany uczony uchodzi za jednego z najważniejszych czeskich historyków. To właśnie on jako pierwszy połączył narodowy entuzjazm z naukowym krytycyzmem, co zaowocowało dziełem Déjiny národu českého v Čechách a v Moravě. Palacký doprowadził zapis czeskich dziejów do 1526 roku. Warto podkreślić, że teksty powstałe po roku 1848 pisane są w języku czeskim: E. Bakke, The Czechoslovak Nation Project and the Slovak Autonomist Reaction 1918-1938, Oslo 1999, s. 125.

32 P.S. Wandycz, Cena wolności. Historia Europy Środkowo-Wschodniej od średniowiecza do współczesności, Kraków 2003, s. 223-224. 
Badacz podkreślał też rolę ruchu husyckiego w stymulowaniu rozwoju ruchów wolnościowych, a nawet szerzeniu idei demokratycznych. W późniejszym okresie nastąpiła jednak polaryzacja czeskich elit intelektualnych i politycznych na tych, którzy większą wagę przywiązywali do aspektów narodowych oraz na zwolenników ideowej interpretacji dziejów. Do grupy upatrującej największej wartości w ciągłości narodowej należeli m.in. Václav Hanka oraz Josef Pekařr33. Drugą grupę reprezentował Tomáš Masaryk, podkreślający rolę ruchu husyckiego oraz szkodliwość katolicyzmu z perspektywy narodowych doświadczeń czeskich ${ }^{34}$. Nie sposób w tym miejscu pominąć, iż niechęć obozu Masaryka miała nie tylko podtekst religijny, ale przede wszystkim polityczny ${ }^{35}$.

Patrząc na politykę historyczną południowego sąsiada Polski, można odnieść wrażenie, że Czesi wciąż są na etapie wyboru wizji swoich dziejów. Nie bez przyczyny dwóch najważniejszych prezydentów w historii najnowszej Republiki Czeskiej wyniosło do rangi mężów opatrznościowych narodu dwóch bohaterów, którzy pozornie nie mają ze sobą nic wspólnego, chociaż tak naprawdę łączy ich bardzo wiele. Jak zauważył Sławomir Nowinowski, Václav Havel konsekwentnie budował wizerunek Tomáša Masaryka jako najważniejszego męża stanu w historii narodu czeskiego. Z kolei Václav Klaus szczególnie chętnie podkreślał rolę Edvarda Beneša ${ }^{36}$. Jak wiemy, drugi $\mathrm{z}$ wymienionych polityków odpowiedzialny jest za wysiedlenie z terenu Czechosłowacji Niemców sudeckich. Decyzję tę można traktować jako wymóg chwili i bieżących realiów politycznych, jednak nie ulega wątpliwości, że wpisuje się ona w syndrom racji stanu kreowanej przez Pragę, z którym nieodłącznie wiąże się walka czeskiego i niemieckiego żywiołu, tak dobitnie przedstawiana przez Palackiego, Hankę

33 Ten pierwszy zasłynął m.in. fałszerstwem staroczeskich poematów, które w zamyśle autora miały dostarczyć dowodów na długą i bogatą tradycję piśmiennictwa: D. Cooper, Mystifications and Ritual Practices in the Czech National Awakening, Washington 2012, s. 1-19.

34 Więcej na temat największej pracy wspomnianego czeskiego męża stanu można przeczytać w: J. Strítecký, The Czech Question a Century Later, „Czech Sociological Review” 1995, no. 1, s. 59-73.

35 W okresie budowy państwa czechosłowackiego po I wojnie światowej kładziono bowiem duży nacisk na rozwój literatury patriotycznej, realizowanie polityki historycznej. Postulat ten przyczyniał się jednak niekiedy do faworyzowania przez władze tych dzieł, które odpowiadały czeskiej racji stanu, bez względu na ich wartość artystyczną. Wspomniane zjawisko spotykało się z kolei ze sprzeciwem środowiska katolickich krytyków literackich, co dodatkowo zaostrzało relacje pomiędzy państwem a katolikami. Przykładem takiego bezkompromisowego krytyka literackiego był Jaroslav Durych: M. Stefański, Jaroslav Durych jako krytyk literacki, „Bohemistyka” 2006, nr 2, s. 135-136.

36 S. Nowinowski, op. cit., s. 50-51. 
i Pekařa ${ }^{37}$. Jednak, jak podkreślił S. Nowinowski, prezydent Klaus nie kontestował polityki historycznej Havla, a jedynie rozszerzył ją o postać Edwarda Beneša. Polski badacz zauważa ponadto, że potrzeba czasu, aby sprawdzić, na ile te dwie tradycje dadzą się pogodzić. Jeżeli jednak tak się nie stanie, to wybranie przez Czechów każdej z nich pociągnie za sobą określone następstwa. W przypadku prymatu motywu walki o niepodległość i zmagania z innymi narodami, zaistnieć może płaszczyzna do walki o interpretację wydarzeń historycznych. W relacjach z Polską objawi się to w budowaniu silnej narracji wobec wydarzeń z XX wieku, jak sprawa Zaolzia oraz „praskiej wiosny”. Jeżeli jednak Czesi pójdą w kierunku interpretacji swoich dziejów jako prekursorów wartości humanistycznych i demokratycznych, narracja ta może sięgnąć po odleglejsze motywy, jak rola ruchu husyckiego. Wydaje się zasadne uznać, że dla relacji polsko-czeskich ta druga ewentualność jest szczęśliwsza.

Zastanawiając się nad pamięcią polsko-czeską dotyczącą najważniejszych wydarzeń w historii Polski, badacz staje nie tylko przed pytaniem, jak przeszłość postrzegana jest przez dany naród. Należy bowiem podkreślić, że niektóre wydarzenia polskiej i czeskiej pamięci zbiorowej powinny być postrzegane nie tylko z perspektywy ogólnonarodowej, ale także lokalnej. Przykładem takiego problemu jest sprawa Zaolzia, która w kontekście ogólnopolskim kojarzona jest przede wszystkim z dyktatem Polski wobec Czechosłowacji w 1938 roku. Znamienne jest, że z perspektywy Polaków mieszkających na obszarze Śląska Cieszyńskiego to tylko element całego ciągu wydarzeń, takich jak interwencja Czechosłowacji w 1919 roku, czy też powrót administracji czechosłowackiej w maju 1945 roku. Czym innym jest jednak polityka historyczna realizowana przez władze danego państwa, a czym innym polityka pamięci praktykowana przez lokalne wspólnoty, które w bezpośredni sposób były uwikłane w sporne wydarzenia. Podkreślał to Maurice Halbwachs, argumentując, iż dane społeczności przeżywają czas inaczej niż reszta sąsiadującej zbiorowości ${ }^{38}$.

Pierwszym aspektem, nad którym należy się pochylić jest oczywiście perspektywa ogólnonarodowa. Zgodnie z tą narracją, sprawa Zaolzia jest wstydliwym epizodem II Rzeczypospolitej, kiedy Polska przyłączyła się do hitlerowskich Niemiec w „gnębieniu złamanej” Czechosłowacji. Wspomniana perspektywa, koncentrująca się na wydarzeniach roku 1938, a pomijająca czechosłowacką agresję w 1919 roku, była nawet wykorzystywana przez polskie elity polityczne. Najdobitniejszym przykładem tego stanowiska jest wystąpienie prezydenta Lecha Kaczyńskiego na Westerplatte z 2009 roku. Jak pamiętamy, przemawiając z okazji 70. rocznicy rozpoczęcia II wojny światowej, głowa

37 E. Bakke, op. cit., s. 125.

38 M. Halbwachs, La Mémoire Collective, Paris 1950, s. 126. 
państwa polskiego uznała zajęcie Zaolzia za przyłączenie się Polski do rozbioru Czechosłowacji, a wręcz grzech ${ }^{39}$. Warto podkreślić, że słowa te zaskoczyły stronę czeską, bowiem, jak zasugerował ambasador Jan Sechter, nikt takiego gestu się nie spodziewał ${ }^{40}$. Co więcej, Polska podobnych słów ze strony swoich południowych sąsiadów również się nie doczekała, chociażby w odniesieniu do sprawy zbrojnego wkroczenia wojsk czechosłowackich na teren Zaolzia w 1919 roku. Powodem tego może być nieprzywiązywanie dużej wagi do wspomnianego wydarzenia, jak również fakt, iż z perspektywy dziejowej konflikt o Śląsk Cieszyński miał dla Czechów korzystny finał.

Tymczasem z perspektywy Polaków mieszkających na obszarze Zaolzia, wkroczenie wojska polskiego w 1938 roku było jedynie epizodem trwającego przez wiele lat zmagania o polskość. O wiele ważniejsza była dla nich masakra pod Stonawą. Lokalna społeczność polska pamięta o tym, że polskich żołnierzy po zamordowaniu rozebrano i tylko dzięki staraniom lokalnego księdza Franciszka Krzystka udało się zorganizować dla nich ubranie, godny pochówek i przez całe lata na mogile pojawiały się świeże kwiaty ${ }^{41}$. Co oczywiste, także prześladowanie polskości na Zaolziu po 1945 roku pozostaje żywe w świadomości polskich mieszkańców Zaolzia, w przeciwieństwie do polskiej pamięci ogólnonarodowej.

Należy podkreślić, że niektóre zagadnienia $\mathrm{z}$ historii są i będą przeżywane odmiennie, w zależności od tego, kogo one dotyczyły. Pamięć lokalnych społeczności wykaże tendencję do nacechowania emocjonalnego. Obiegowa opinia funkcjonująca w narodzie polskim i czeskim będzie zapewne bardziej wyważona. Wreszcie, z perspektywy polskiej i czeskiej elity politycznej, omawiany problem traktowany będzie bez większych emocji, a sama historia pozostanie jedynie narzędziem w realizacji racji stanu.

Na postrzeganie wspólnej przeszłości polsko-czeskiej niebagatelny wpływ mają niewątpliwie stereotypy. Zgodnie z przywołanym wcześniej sondażem z 1988 roku, wizerunek naszych południowych sąsiadów był jednoznacznie negatywny ${ }^{42}$. Czechom zarzuca się, że są obłudni, przebiegli, tchórzliwi i służalczy. Trudno nie zgodzić się ze stwierdzeniem, że wspomniane cechy mogą mieć swoje korzenie także $\mathrm{w}$ ich historii. Jak bowiem wskazują interakcje

39 http://wpolityce.pl/wydarzenia/14431-przemowienie-sp-prezydenta-kaczynskiego-na -westerplattez-okazji-70-rocznicy-wybuchu-ii-wojny-swiatowej-w-obecnosci-wladimira-putina [dostęp: 16.03.2015].

40 http://wiadomosci.wp.pl/kat,1342,title,Ambasador-Czech-Lech-Kaczynski-wykonalniezwykly-gest,wid,11454266,wiadomosc.html?ticaid=1e6b7 [dostęp: 16.03.2015].

${ }^{41}$ A. Sęk, Czeskie zbrodnie zagłady polskości Śląska Zaolziańskiego można wybaczyć, lecz nie wolno o nich zapomnieć, „Zaolzie - Polski Biuletyn Informacyjny” 2006, nr 1, s. 1-3.

${ }^{42}$ T. Jastrun, op. cit., s. 56. 
polsko-czeskie, obie strony miały prawo wynieść z nich nie najlepsze wspomnienia. Niektóre przypisywane Czechom przywary mają jednak charakter generalny i trudno je wytłumaczyć jako efekt kolizji interesów dwóch narodów. Wspomniane wady mają swoje korzenie gdzie indziej.

Jedną z cech szczególnie chętnie przypisywanych Czechom jest dwulicowość oraz służalczość wobec silniejszych sąsiadów. Opinia ta ma podwójne korzenie. Warto pamiętać, że w okresie rozbiorów na terenach zaboru austriackiego Polacy dość często stykali się z Czechami. Ci ostatni, ze względu na długoletnią relację z Niemcami, znali dobrze język naszego zaborcy. Z tego powodu byli chętnie zatrudniani przez Austriaków jako urzędnicy niższego szczebla na terenie ówczesnej Galicji, co skutkowało tym, że ich kontakty z Polakami były na porządku dziennym ${ }^{43}$. Nie jest tajemnicą, że tego typu interakcje mogły mieć charakter korupcjogenny, a tym samym przyczyniały się do negatywnego wizerunku naszych południowych sąsiadów. Nie jest to wszelako jedyny możliwy korzeń wspomnianego stereotypu.

Jak już wspomnieliśmy wyżej, Czesi uznają za jeden z naczelnych tematów swoich dziejów zmaganie z żywiołem niemieckim i walkę o własną tożsamość narodową. Wiadomym również, że w II połowie XIX wieku ważyła się na salonach Wiednia reforma ustroju monarchii habsburskiej. Jedną z koncepcji rywalizujących z pomysłem budowy Austro-Węgier była właśnie idea podniesienia Czech do rangi jednego z najważniejszych członów nowego państwa ${ }^{44}$. Rzecz jasna, ostatecznie zwyciężyła orientacja prowęgierska, co wielu czeskich buditeli odebrało jako wielkie rozczarowanie ${ }^{45}$. W takiej sytuacji dużą popularnością zaczęła się cieszyć sympatia wobec Rosji oraz promowanej przez nią koncepcji panslawizmu ${ }^{46}$. Nie jest tajemnicą, że w owym czasie orientacja Polaków wobec Rosjan była zdecydowanie negatywna. Z tego powodu utarło się

${ }^{43}$ Co więcej, Czech jako aparatczyk to efekt obecności wielu Czechów w austriackiej biurokracji, gdzie w zaborze zetknęli się z Polakami - A. Kroh, Polak Czech dwa bratanki, [w: Narody i stereotypy, T. Walas (red.), Kraków 1995, s. 43.

44 Nie był to zresztą postulat nowy. Czesi po raz pierwszy wysunęli to żądanie w sposób radykalny w 1848 roku w czasie Wiosny Ludów: M. Żywczyński, Historia powszechna 1789-1870, Warszawa 1997, s. 371. Od tego czasu elity czeskie niezmiennie monitowały władze austriackie do wprowadzenia rozwiązań federacyjnych. Szczególnie bolesny zawód spotkał Czechów właśnie w 1867 roku, gdy zdecydowano o wyniesieniu do rangi drugiego najważniejszego elementu cesarstwa korony węgierskiej. Ibidem, s. 494-495.

45 Szczególnie cenne informacje znaleźć można w siódmym rozdziale pracy E. Bakke, op. cit., s. 134-156.

46 Według wspomnianej koncepcji miało nastąpić zjednoczenie wszystkich Słowian pod berłem rosyjskim: D. Bielec, Czescy autorzy w polskim drugim obiegu a polsko-czeskie stereotypy, „Bohemistyka” 2008, nr 4, s. 118-119. 
w mentalności polskiej przekonanie, że Czesi są służalczy, choć w rzeczywistości poszukiwali oni pomocy w realizacji swojego narodowego paradygmatu ${ }^{47}$.

Drugim i równie silnym stereotypem zakorzenionym w mentalności obu narodów jest podejście do spraw religijnych. Nie od dziś bowiem wiadomo, że Czesi postrzegają automatycznie Polaków jako gorliwych katolików, zaś mieszkańcy Polski uznają czeskich sąsiadów za ateistów. Przyczyny takich wyobrażeń są dość jasne i mają swoje uzasadnienie w historii. Jak słusznie wskazuje Elżbieta Szczepańska, zarówno ruch husycki oraz narzucony w XVII wieku przez zwycięskich Habsburgów katolicyzm i prześladowania Kościoła w okresie komunizmu nie tylko mogły odstręczać Czechów od wiary. Utożsamili oni ją z czynnikami zwalczającymi narodowość czeską ${ }^{48}$. Jak wiadomo, odwrotnie było na ziemiach polskich, gdzie katolicy musieli zmagać się w imię tożsamości narodowej z protestanckimi Niemcami i prawosławnymi Rosjanami.

Na wzajemne postrzeganie Czechów i Polaków wywiera zatem wpływ pamięć zbiorowa obu narodów. Czynnikiem utrudniającym budowę spójnego obrazu jest, przede wszystkim, trwająca wśród naszych południowych sąsiadów dyskusja dotycząca wizji i sensu dziejów. Jeżeli wśród Czechów zwycięży idea wielowiekowej walki z żywiołem niemieckim, to wszystkie wydarzenia, w których Polska działała przeciw południowym sąsiadom będą wzmacniać negatywny obraz Polaków. Ze względu na fakt, że udział armii PRL w tłumieniu „praskiej wiosny” był efektem ograniczonej suwerenności Polaków, jedynym polem napięcia we wzajemnej pamięci zbiorowej jest sprawa Zaolzia. Z perspektywy polskiej optymalnym rozwiązaniem byłoby przeciwstawienie agresji polskiej z 1938 roku inwazji czechosłowackiej 1919 roku i wzajemne pojednanie. O ile jednak Polacy dość łatwo wyrażają skruchę „za Zaolzie”, o tyle nieśmiało domagają się podobnych gestów ze strony Czechów za masakrę pod Stonawą. Powód takiego działania stanowi polska zależność od autostereotypu, zgodnie z którym naród polski nie jest agresorem. Łatwiej nam więc przyznać się do winy niż domagać się sprawiedliwości. Drugą płaszczyzną różniącą nasze narody na poziomie stereotypów jest religia. Dla Polaków, którzy w swojej mitologii narodowej wysoko postawili mesjanizm, wiara to integralny element

47 E. Szczepańska przekonuje, że wpływ poszczególnych wydarzeń, przeżywanych odmiennie przez Czechów i Polaków przyczyniał się do pogłębiania istniejących i tworzenia nowych stereotypów. Przykładem takiego procesu było narastające u naszych południowych sąsiadów rusofilstwo, do którego Polacy mieli krytyczne nastawienie. Także sprawa Zaolzia, stanowiąca $\mathrm{w}$ istocie klasyczny konflikt terytorialny nie mogła przyczynić się do budowania transgranicznej przyjaźni. Nie sposób wreszcie pominąć przykładu "praskiej wiosny” w popularyzowaniu nieprzyjaznych skojarzeń pomiędzy obydwoma narodami: E. Szczepańska, op. cit., s. 288.

48 Ibidem, s. 292. 
tożsamości. Co więcej, religijność ta ma charakter wybitnie katolicki, bowiem wyostrza dodatkowo różnice wobec protestanckich Niemców oraz prawosławnych Rosjan, sprawców polskiego cierpienia. Z kolei dla Czechów religia katolicka nie może kojarzyć się inaczej niż z opresyjną inkwizycją, która pojawiła się w ich kraju „nazajutrz” po tragedii roku 1620.

\section{Historia jako element polityki. Ewolucja pamięci zbiorowej}

Wspomniane wyżej okoliczności w naturalny sposób przyczyniły się do powstania negatywnego lub w najlepszym razie odległego wizerunku Polaków i Czechów w pamięci zbiorowej obu narodów. Warto jednak zapytać, czy owa tożsamość jest na tyle ustabilizowana, że nie będzie możliwa jej zmiana jakościowa. Próbą takiego oddziaływania jest polityka pamięci prowadzona przez Polskę i Czechy zarówno w wymiarze ogólnonarodowym, jak i lokalnym.

Jedną $\mathrm{z}$ prób oddziaływania na pamięć zbiorową $\mathrm{w}$ wymiarze ogólnonarodowym było wystąpienie prezydenta Lecha Kaczyńskiego z 2009 roku. Argumentem przemawiającym za tym, że „przeprosiny za Zaolzie” stały się elementem polskiej polityki zagranicznej jest fakt, że wspomniane oświadczenie zostało wygłoszone w obecności Władimira Putina, w dniu 70. rocznicy wybuchu II wojny światowej oraz w kontekście pamięci o zbrodni katyńskiej ${ }^{49}$. Warto przypomnieć, że o ile prezydent Kaczyński przeprosił Czechów za polską agresję z 1938 roku, to nie wspomniał o agresji czechosłowackiej z 1919 roku. Takie działanie należy rozpatrywać jako element polityki pamięci, niemającej jednak wiele wspólnego z prawdą historyczną. Warto nadmienić, że o ile zabieg ten nie przyniósł spodziewanych rezultatów w odniesieniu do stosunków z Federacją Rosyjską, o tyle słowa prezydenta Kaczyńskiego „oburzyły” w znacznej mierze Polaków mieszkających na terenie Śląska Cieszyńskiego. To właśnie ta druga perspektywa polska, o której trzeba wspomnieć. Wybór pomiędzy aktualną wykładnią racji stanu a prawdą historyczną należy niewątpliwie do najtrudniejszych dylematów politycznych. Z jednej strony należy uznać, ze państwo polskie powinno zabiegać o prawdziwy obraz przeszłości, zwłaszcza jeżeli w grę wchodzi los Polaków. Z drugiej strony trudno sobie wyobrazić, aby elity rządzące zostały pozbawione prerogatyw w zakresie kreowania polityki pamięci, co niemal zawsze wiąże się $\mathrm{z}$ naciskiem na wybrane zagadnienia $\mathrm{z}$ historii.

Ciekawym przykładem tworzenia rytuałów wspólnej pamięci zbiorowej w wymiarze lokalnym jest polsko-czeskie obchodzenie Święta Trzech Braci

${ }^{49}$ H. Rusek, A. Kasperek, op. cit., s. 102-104. 
poświęconego założeniu Cieszyna w 810 roku. Co ciekawe, w działania na rzecz przygotowania świętowania tych obchodów zaangażowane są zarówno polskie, jak i czeskie organizacje ${ }^{50}$. Warto zwrócić przy tej okazji uwagę na dwie sprawy. Po pierwsze, jedność tworzona w ramach tego typu świąt ma charakter sztuczny. Oto bowiem w grę wchodzi nawiązanie do przeszłości o charakterze nie tylko mitycznym. Co więcej, wspomniane wydarzenie umiejscowione jest w tak odległej przeszłości, że jego oddziaływanie jest stosunkowo niewielkie. Być może jednak paradoksalnie w tym tkwi siła wspomnianej inicjatywy. Warto w tym miejscu przywołać poglądy Karen Armstrong, dowodzące, że w ostatecznym rozrachunku liczy się nie tyle prawdziwość podstaw danego mitu, co jego skuteczność ${ }^{51}$. Wydaje się dość prawdopodobne, że wspomniana uroczystość ma szansę stać się próbą budowania zgody pomiędzy mieszkańcami obu części Śląska Cieszyńskiego. Fundamentem owego zbliżenia będzie jednak nie samo wydarzenie, którego autentyczności nie sposób obecnie zweryfikować, ale właśnie współczesna uroczystość, stanowiąca wspólny rytuał angażujący przedstawicieli obu nacji.

Zmiana wzajemnego postrzegania Czechów i Polaków jest zatem możliwa, choć proces ten wymaga świadomych działań na polu pamięci zbiorowej. Dzieje się to przede wszystkim poprzez świadome podkreślanie przez czeskie i polskie elity polityczne tych aspektów wspólnej historii, które mogą pobudzić pozytywne skojarzenia względem sąsiada. Nieodłączną częścią tego procesu jest jednak również pojednanie w odniesieniu do trudnych momentów historii. W przypadku stosunków polsko-czeskich należałoby więc połączyć żal za aneksję Zaolzia w 1938 roku z oczekiwaniem wobec Czechów, że i oni uznają wkroczenie armii czechosłowackiej na teren Śląska Cieszyńskiego w 1919 roku za agresję. Drugą kategorią działań wzmacniających pozytywną identyfikację w czesko-polskiej pamięci zbiorowej są inicjatywy oddolne, podejmowane np. na terenach granicznych. Opisane wyżej działania byłyby jednak najskuteczniejsze, gdyby podejmowane były w skoordynowany sposób, w ramach długofalowej strategii.

\section{Ewolucja pamięci zbiorowej}

Warto jednak pamiętać, że pamięć zbiorowa często ewoluuje w sposób niekontrolowany przez elity polityczne lub społeczeństwo. Tak dzieje się również w przypadku czeskim, co przyczyniło się do przezwyciężenia lub przynajmniej złagodzenia niektórych stereotypów. Przykładem takiej ewolucji jest chociażby

${ }_{50}$ http://www.swietotrzechbraci.pl/pages/info.php [dostęp: 3.11.2015].

51 K. Armstrong, Krótka historia mitu, Kraków 2005, s. 13. 
największy mit narodowy, odnoszony do bitwy pod Białą Górą. Dowodem na to, że Czesi nie chcą już postrzegać lat 1620-1918 jako „czasu straconego” (lub temno) są powtarzające się głosy czeskich intelektualistów nawołujących do przewartościowania dorobku czeskiego w okresie od stłumienia wspomnianego powstania do uzyskania przez Czechosłowację niepodległości. Jak podkreśla Elisabeth Bakke, wydarzenie, które symbolizuje Biała Góra zapoczątkowało co prawda exodus protestanckich uczonych i doprowadziło do okresowej marginalizacji języka czeskiego. Trzeba jednak pamiętać, że owych protestanckich uczonych zastąpili twórcy posługujący się niemieckim oraz łaciną. Znaczącą rolę zaczęło również odgrywać szkolnictwo jezuickie, które w XVII w. reprezentowało wysoki poziom ${ }^{52}$. O krok dalej idzie Ludmila Lantová, wedle której ponownej ocenie powinna zostać poddana katolicka kultura czeska, która swój dobry czas rozpoczęła właśnie w XVII wieku ${ }^{53}$. Warto wreszcie wskazać na opinię intelektualistów z okresu tuż przed powstaniem Republiki Czechosłowackiej. Już w 1917 roku grupa pisarzy katolickich podkreślała otwarcie, że odrodzenie narodu czeskiego nie będzie możliwe ani pełne, jeżeli zostanie przeprowadzone w oderwaniu od jego chrześcijańskiego, w tym katolickiego, dziedzictwa ${ }^{54}$. Czesi już jakiś czas temu zaczęli więc dostrzegać, że na ich dorobek kulturowy składają się różne doświadczenia, także te, które wcześniej uznawano za negatywne. Dowodów na poparcie tej tezy dostarcza m.in. architektura czeska. Dobrym przykładem takiego cywilizacyjnego dorobku, w którym obecne są zarówno elementy pożądane, jak i długo przez Czechów negowane jest Most Karola. Konstrukcja znajdująca się w stolicy została ufundowana przez Karola IV po powodzi, która zniszczyła starszy, drewniany most w 1342 roku. Ciekawe jest jednak to, że największe prace zdobnicze, polegające na wyrzeźbieniu i ustawieniu 28 najważniejszych figur przedstawiających mę-

52 Jak więc podkreśla badaczka, o zapaści w sferze kulturowej nie może być mowy: E. Bakke, op. cit., s. 103. Jak zauważa A. Pająk, nawet Josef Pekař przyznawał, że w niektórych aspektach, takich jak muzyka barokowa i sztuka czeska kultura rozwijała się bardzo prężnie: A. Pająk, op. cit., s. 85.

53 L. Lantová, Miloš Marten, [w:] Lexikon české literatury. Osobnosti, díla, instituce, Praha 2000, s. 122.

${ }_{54}$ M. Stefański, Czeska krytyka katolicka lat 1918-1938, Warszawa 2007, s. 25. Warto w tym miejscu podkreślić opinię Michała Stefańskiego, który słusznie dowodzi rosnącego wśród Czechów zainteresowania poglądami katolickich myślicieli, literatów i krytyków. Więcej na ten temat czytaj u: M. Stefański, O krytyce Jana Strakosa, „Bohemistyka” 2005, nr 4, s. 249-251. Linia sporu pomiędzy katolickimi intelektualistami a szczególnie krytykami literackimi i twórcami w powstającym po I wojnie światowej państwie biegła jednak nie tyle przez kwestie religijne, co poziom dzieł, mających przecież uzasadniać i umacniać patriotyzm w tworzącym się państwie. Więcej na ten temat czytaj w: ibidem, s. $135-148$. 
żów stanu i świętych Kościoła katolickiego odbyły się w okresie 1659-1714 ${ }^{55}$. Wspomniany przykład jasno dowodzi, że po 1620 roku działy się w czeskiej kulturze rzeczy ważne, nawet jeżeli kierunek przemian był dla samych Czechów bolesny. Nasi południowi sąsiedzi zdają sobie sprawę z faktu, że nie stać ich na wymazanie z pamięci 300 lat swojej historii.

Zarówno więc fakt, iż Czesi większą wagę przywiązują do swojego dziedzictwa z okresu XX stulecia, jak również dystans do klęski pod Białą Górą, a wreszcie obecność innych punktów spornych w historii polsko-czeskiej sprawia, że omawiana batalia nie jawi się jako znaczący przyczynek do wzajemnej niechęci. Nadmienić należy, iż postulowana zmiana oceny chrześcijańskiego dorobku cywilizacyjnego Czech, w tym okresu po 1620 roku, nie wynika ze wzrostu popularności religii katolickiej. Jak wskazała ankieta przeprowadzona przez czeską telewizję w 2005 roku, za najwybitniejszą postać nasi południowi sąsiedzi uznają Karola IV Luksemburskiego, który uzyskał więcej głosów niż Tomáš Masaryk ${ }^{56}$. Rozważając zagadnienie pamięci zbiorowej Czechów i polityki historycznej południowego sąsiada Polski, należy sobie również zdać sprawę z tego, że nie jest to zagadnienie kluczowe z punktu widzenia całego społeczeństwa. Jak wskazują wyniki badań przeprowadzonych w Pradze w 2013 roku, zaledwie 53\% respondentów uznało, iż znajomość historii jest bardzo ważna. W sumie $42 \%$ badanych było zdania, iż kwestia ta jest relatywnie nieistotna lub zgoła nieważna ${ }^{57}$.

Współczesne sondaże wskazują na poprawę wizerunku naszych południowych sąsiadów w oczach Polaków. Zgodnie ze współczesnymi badaniami, aczkolwiek Czesi nadal uchodzą za kapitulantów, to jednak przypisuje się im również pozytywne cechy, takie jak łagodny charakter, pogodę ducha i zamiłowanie do piwa ${ }^{58}$. Jak podkreśla Renata Rusin-Dybalska, zgodnie z wynikami badania przeprowadzonego przez CBOS w lutym 2011 roku, wśród wszystkich obcych narodów najbardziej przypadli do gustu Polakom właśnie Czesi (51\% respondentów). Na drugim i trzecim miejscu znaleźli się Słowacy i Amerykanie (odpowiednio $49 \%$ i $43 \%)^{59}$. Do wspomnianych sondaży należy podchodzić oczywiście z dużą dozą ostrożności. Powszechnie bowiem wiadomo, że zarówno Polacy, jak i Czesi co innego myślą o sobie, a co innego pragną

55 H. Louthan, op. cit., s. 3.

56 S. Nowinowski, op. cit., s. 48.

57 J. Šubrt, Historical Consciousness and the Teaching of History in the Czech Republic, "Studia Edukacyjne” 2013, no. 24, s. 201.

58 Warto zauważyć, że im bardziej współczesne sondaże, tym bardziej pozytywny obraz Czechów: D. Bielec, op. cit., s. 133-134.

59 R. Rusin-Dybalska, Czego Czesi dowiadują się o Polakach a Polacy o Czechach, „Język, Komunikacja, Informacja” 2011, nr 6, s. 176. 
upowszechniać jako prawdziwe wśród sąsiadów ${ }^{60}$. Warto jednak pamiętać, że oba narody przypisują sobie samym podobne wady i zalety ${ }^{61}$. Niezależnie od tego, iż oba narody może jeszcze coś dzielić, to jednak łączą je niewątpliwie podobne dzieje oraz wiele rzeczy wspólnych. Wspomnieć wystarczy choćby wkład czeski w chrystianizację Polski. Dotyczy to zarówno samego chrztu, jak i postaci św. Wojciecha - jednego z najważniejszych świętych czczonych przez Polaków ${ }^{62}$.

Można sądzić, że jakkolwiek stosunki polsko-czeskie miały dość liczne trudne momenty, to wizerunek Czechów w oczach Polaków przeszedł w ciągu wieków długą drogę. Niemała w tym zasługa środowisk opozycyjnych obu krajów. Negatywne wspomnienia odnoszące się do bitwy pod Białą Górą, Zaolzia, a także „praskiej wiosny” nie zostały zupełnie wyeliminowane z czeskiej świadomości zbiorowej, ale wzbogacono je o pozytywne doświadczenia z okresu współczesnego. Oba narody weszły do Unii Europejskiej oraz NATO i nie jest tajemnicą, że uczyniły tak z tego samego powodu. Zarówno Polska, jak i Czechy są zainteresowane walką o fundusze europejskie, co czyni ich zazwyczaj partnerami (choć niekiedy także rywalami). Wydaje się więc, że w nadchodzących latach poczucie wspólnoty pomiędzy Polakami i Czechami ma szansę się pogłębiać. Oba narody wchodzą w skład Grupy Wyszehradzkiej, ale także kojarzone są przez zachodnie kraje jako „nowi” członkowie Unii Europejskiej. Kolejnym punktem łączącym Polskę i Czechy jest zatem jednomyślność w popieraniu korzystnych i zwalczaniu negatywnych projektów politycznych forsowanych przez kraje „starej unii”. Przykładem takiej jedności jest stanowisko rządów Polski i Czech w kwestii przymusowej relokacji uchodźców.

\section{Podsumowanie}

Reasumując, należy stwierdzić, że relacje Polski i Czech mają unikatowy charakter. $Z$ jednej bowiem strony uobecniane są w pamięci zbiorowej pozytywne skojarzenia wobec naszego południowego sąsiada (jak np. udział w chrystianizacji Polski). Z drugiej strony nie wygasły jeszcze niektóre urazy, szczególnie te odniesione przez obie strony w toku trudnego wieku XX. W kontaktach pomiędzy państwami wzajemne stosunki są zazwyczaj relatywnie dobre,

60 A. Meštan wspomina w swojej pracy, że istotnie każda z nacji pokazuje sąsiadowi jedynie tę stronę, która wydaje mu się odpowiednia. Prowadzi to niekiedy do zabawnych sytuacji, gdy jedna strona naraża się na negatywne postrzeganie ze względu na uprzedzenia drugiej strony. Takim przykładem są np. nieporozumienia natury językowej: A. Meštan, Czeski stereotyp Czechów a czeski stereotyp Polaków, [w:] T. Walas (red.), op. cit., s. 35-40.

61 Ibidem, s. 37.

${ }^{62}$ Więcej na ten temat: D.A. Sikorski, Kościół w Polsce za Mieszka I i Bolesława Chrobrego, Poznań 2013. 
aczkolwiek komplikacje pojawiają się niekiedy w wymiarze lokalnym. Warto jednak podkreślić, że i w tym przypadku strony podejmują mniej lub bardziej udane próby tworzenia nowych punktów odniesienia dla wspólnej pamięci, takich jak chociażby Święto Trzech Braci. Najlepszym dowodem poprawy postrzegania Czechów przez Polaków jest złagodzenie stereotypów, które obecnie w najgorszym razie mają charakter ambiwalentny (kapitulanci, ale pogodni i weseli). Niektóre z owych złych wyobrażeń, zarówno po polskiej, jak i czeskiej stronie zostały złagodzone także poprzez postawy opozycjonistów antykomunistycznych z obu krajów w latach 70. XX wieku' ${ }^{63}$.

Gdy idzie o konkretne zdarzenia wzajemnych relacji, to najgłośniejszy czeski mit narodowy, mianowicie bitwa pod Białą Górą, nie posiada ostrza antypolskiego. Problem Zaolzia jest nieco bardziej złożony. W dyskursie międzynarodowym Polska wyraziła żal za agresję na Czechosłowację w 1938 roku, co Czesi przyjęli jako miły, choć niespodziewany gest. Problemem jest jednak brak podobnego gestu ze strony naszych południowych sąsiadów w odniesieniu do wydarzeń roku 1919. Warto nadmienić, że wspomniane sytuacje są bardzo podobne. Tak jak Polacy wykorzystali presję niemiecką na Czechosłowację, tak nasi południowi sąsiedzi wkroczyli zbrojnie na sporny teren Śląska, gdy II Rzeczpospolita zmagała się z zagrożeniem sowieckim. W sferze lokalnej kontrastują wciąż ze sobą poczucie urazy oraz postulat budowania lepszych stosunków ${ }^{64}$. Ocena postawy Polaków w czasie "praskiej wiosny” jest o tyle utrudniona, że decyzja o interwencji nie stanowiła suwerennej decyzji Polski, o czym Czesi wiedzą, mimo że w czasie trwania samego konfliktu wyrażali sprzeciw wobec obecności wojsk PRL.

Należy wreszcie zauważyć, że polsko-czeskie relacje wykazują znaczną stabilność, w przeciwieństwie do kontaktów Polski z Litwą. Dzieje się tak za sprawą wciąż żywych i brzemiennych konfliktów pomiędzy dawnymi krajami Rzeczypospolitej Obojga Narodów. Patrząc na bieg swoich dziejów, Litwini mogą mieć bowiem poczucie, że ich kraj stracił na sile i znaczeniu w wyniku unii z Rzecząpospolitą. Co więcej, oba narody pozostawały ze sobą w o wiele bliższych relacjach niż Polska i Czechy. $Z$ całą pewnością możemy zatem stwierdzić, że, na tle mniej lub bardziej nabrzmiałych konfliktów międzynarodowych w sferze pamięci historycznej, obecne relacje Czechów i Polaków należy uznać za dobre.

${ }^{63}$ Przykładem może być współpraca pomiędzy czeskimi opozycjonistami z Karty 77 a przedstawicielami polskiego KOR-u w 1978 roku: P. Blažek, Akcja „Červotoč” (Kołatek). Tajny wspótpracownik StB Stanislav Dvořák jako kurier Solidarności Polsko-Czechosłowackiej, „Pamięć i Sprawiedliwość” 2006, nr 9, s. 117-164.

64 Przykładem na poparcie wspomnianej tezy może być cytowany w tym tekście kilkukrotnie periodyk „Zaolzie”. Chęć poprawy relacji polsko-czeskich nie jest ani całkowita, ani bezwarunkowa. 


\section{Bibliografia}

Armstrong K., Krótka historia mitu, Kraków 2005.

Bakke E., Doomed to Failure? The Czechoslovak Nation Project and the Slovak Autonomist Reaction 1918-1938, Oslo 1999.

Bielec D., Czescy autorzy w polskim drugim obiegu a polsko-czeskie stereotypy, „Bohemistyka” 2008, nr 4, s. 116-136.

Cooper D., Mystifications and Ritual Practices in the Czech National Awakening, Washington 2012.

Dojnik J., Mity narodowe a myślenie polityczne, [w:] Mity historyczno-polityczne, wyobrażenia zbiorowe, polityka historyczna. Studia $i$ materiały, t. 1, E. Ponczek, A. Sepkowski (red.), Toruń 2010, s. 44-55.

Gąsior G., Stawianie granicy, „Karta. Kwartalnik Historyczny” 2008, nr 55, s. $2-36$.

Hájková D., Wingfield N.M., Czech(-oslovak) National Commemorations During the Interwar Period: Tomáš G. Masaryk and the Battle of White Mountain Avenged, „Acta Histriae”, 2010, no. 18, s. 425-452.

Halbwachs M., La Mémoire Collective, Paris 1950.

Jastrun T., Hipopotam, czyli jak polska młodzież licealna widzi Czechosłowacje, „Res Publica” 1988, nr 12, s. 52-57.

Kalous J., Reakcje społeczeństwa Czechosłowackiego na udział Polski $w$ interwencji 1968 roku, [w:] Wokół Praskiej Wiosny, Ł. Kamiński (red.), Warszawa 2004, s. 117-137.

Kowalski L., Kryptonim „Dunaj”: udział wojsk polskich $w$ interwencji zbrojnej w Czechosłowacji w 1968 roku, Warszawa 1992.

Kroh A., Polak Czech dwa bratanki, [w:] Narody i stereotypy, T. Walas (red.), Kraków 1995, s. 43-46.

Lantová L., Miloš Marten, [w:] Lexikon české literatury. Osobnosti, díla, instituce, Praga 2000, s. 121-124.

Louthan H., The Charles Bridge and Czech Identity, Washington 2006.

Markiewicz M., Historia Polski 1492-1795, Kraków 2004.

Matouš V., Juza J., Svědectví o roku 1968 v okrese Rychnov n.Kn., Rychnov nad Kněžnou 1992.

Meštan A., Czeski stereotyp Czechów a czeski stereotyp Polaków, [w:] Narody $i$ stereotypy, T. Walas (red.), Kraków 1995, s. 35-41.

Nowinowski S., Glosa do sporu o sens czeskich dziejów, [w:] Pamięć i polityka historyczna. Doświadczenia Polski i jej sąsiadów, S.M. Nowinowski, J. Pomorski, R. Stobiecki (red.), Łódź 2008, s. 43-52.

Pająk A., Głos Miloša Martena w sporze o sens czeskich dziejów, „Bohemistyka” 2009, nr 2, s. 81-89. 
Pekař J., O smyslu českých dějin, Praha 1999.

Rusek H., Kasperek A., Sympatie i antypatie polsko-czeskie w świetle badań nad antagonizmem i pojednaniem polsko-czeskim na Śląsku Cieszyńskim wraz z francusko-niemieckim case study, [w:] Pogranicze - Sąiedztwo - Stereotypy. Przypadek polsko-czeskich relacji, A. Kasperek (red.), Katowice-Cieszyn 2012, s. 97-129.

Rusin-Dybalska R., Czego Czesi dowiaduja się o Polakach a Polacy o Czechach, „Język, Komunikacja, Informacja” 2011, nr 6, s. 167-177.

Sepkowski A., Człowiek w przestrzeni mitycznej, [w:] Mity historyczno-polityczne, wyobrażenia zbiorowe, polityka historyczna. Studia i materialy, t. 1, E. Ponczek, A. Sepkowski (red.), Toruń 2010, s. 13-29.

Sęk A., Czeskie zbrodnie zagłady polskości Ślaska Zaolziańskiego można wybaczyć, lecz nie wolno o nich zapomnieć, „Zaolzie - Polski Biuletyn Informacyjny" 2006, nr 1, s. 1-8.

Sęk A., Zawieruchy wojennej ciąg dalszy, „Zaolzie. Polski Biuletyn Informacyjny" 2004, nr 11, s. 1-7.

Sikorski D.A., Kościót w Polsce za Mieszka I i Bolesława Chrobrego, Poznań 2013.

Stefański M., Jaroslav Durych jako krytyk literacki, „Bohemistyka” 2006, nr 2, s. $135-148$.

Stefański M., O krytyce Jana Strakosa, „Bohemistyka” 2005, nr 4, s. 249-264.

Strítecký J., The Czech Question a Century Later, „Czech Sociological Review” 1995, no. 1, s. 59-73.

Šubrt J., Historical Consciousness and the Teaching of History in the Czech Republic, „Studia Edukacyjne” 2013, nr 24, s. 195-223.

Szczepańska E., Wizerunek Czecha $w$ „Zrób sobie raj” czy może kreowanie nowych stereotypów, „Bohemistyka” 2013, nr 4, s. 286-296.

Ślusarczyk Z., Opowieści spod spadochronowej czaszy, Kraków 1992.

Wandycz P.S., Cena wolności. Historia Europy Środkowo-Wschodniej od średniowiecza do współczesności, Kraków 2003.

Zückert M., Zwischen Nationsidee und staatlicher Realität. Die tschechoslowakische Armee und ihre Nationalitätenpolitik 1918-1938, München 2006.

Żywczyński M., Historia powszechna 1789-1870, Warszawa 1997.

http://www.swietotrzechbraci.pl/pages/info.php [dostęp: 3.11.2015].

http://wiadomosci.wp.pl/kat,1342,title,Ambasador-Czech-Lech-Kaczynski -wykonal-niezwykly-gest,wid,11454266, wiadomosc.html?ticaid=1e6b7 [dostęp: 16.03.2015].

http://wpolityce.pl/wydarzenia/14431-przemowienie-sp-prezydenta-kaczynskiego-na-westerplattez-okazji-70-rocznicy-wybuchu-ii-wojny-swiatowej-w-obecnosci-wladimira-putina [dostęp: 16.03.2015]. 


\begin{abstract}
It is not a secret that Czech nation played important role in Polish history. What is most striking, however, our southern neighbour do not occupy key position in Polish collective memory. It is worth considering why both nations are not closely integrated despite joint participation in so many seminal moments of history. In the first part of this paper I will aim at defining key events that shaped Czech collective memory. Next, I will make an attempt to answer why in some of these Polish and Czech people retained divergent visions of the past. Finally, I will try to point to some attempts undertaken by both nations in order to bridge the gaps in collective memory.
\end{abstract}

Keywords: collective memory, historical policy, history, sociology 